\title{
Associated factors with excessive weight gain in pregnant women from Maceió, Northeastern Brazil
}

\author{
Fatores associados ao ganho ponderal excessivo em gestantes de \\ Maceió, Nordeste do Brasil
}

Raphaela Costa Ferreira (https://orcid.org/0000-0002-1613-8819) ${ }^{1}$

Micaely Cristina dos Santos Tenório (https://orcid.org/0000-0002-1771-489X) ${ }^{2}$

Marilene Brandão Tenório (https://orcid.org/0000-0002-7504-0491) ${ }^{3}$

Carolina Santos Mello (https://orcid.org/0000-0001-6461-1749) ${ }^{4}$

Alane Cabral Menezes de Oliveira (https://orcid.org/0000-0002-7497-919X) ${ }^{2}$
${ }^{1}$ Instituto de Ciências Biológicas e da Saúde, Universidade Federal de Alagoas (UFAL). Av. Lourival Melo Mota s/n, Tabuleiro do Martins. 57072-900 Maceió AL Brasil.raphinhacosta2010@ hotmail.com

${ }^{2}$ Faculdade de Nutrição,

UFAL. Maceió AL Brasil.

${ }^{3}$ Rede Nordeste de

Biotecnologia, UFAL.

Maceió AL Brasil.

${ }^{4}$ Escola de Nutrição,

Universidade Federal de

Bahia. Salvador BA Brasil.
Abstract This article aims to evaluate the associated factors with excessive weight gain in pregnant women from Maceio, the capital of Alagoas, Northeastern Brazil. Cross-sectional study with pregnant women attended in public health in the city of Maceió in 2014, of which socioeconomic, clinical (glycemia, capillary hemoglobin, and blood pressure measurement), dietary, and anthropometric data, including in the latter gestational weight gain, classified as insufficient, adequate and excessive according to the US Institute of Medicine, were collected. The combination of excessive weight gain with the independent variables was tested using the Poisson regression expressed by the Prevalence Ratio (PR) and a 95\% confidence interval ( $\left.\mathrm{CI}_{95 \%}\right)$. We studied 403 pregnant women with a mean age of $24.08 \pm 6.01$ years, with $19.9 \%$ of them displayed insufficient weight gain; $14.1 \%$ displayed adequate weight gain, and $66.0 \%$ displayed excessive weight gain, that was associated with maternal hyperglycemia $(P R=$ 1.35; $C I_{95 \%}=1.17$ to 1.57; $p<0.001$ ). Excessive weight gain is common among pregnant women evaluated with the association of this variable with maternal hyperglycemia.

Key words Weight gain, Hyperglycemia, Prenatal care
Resumo $O$ objetivo deste artigo é avaliar os fatores associados ao ganho ponderal excessivo em gestantes de Maceió, capital do estado de Alagoas, Nordeste do Brasil. Estudo transversal realizado com gestantes assistidas pela rede pública de saúde do município de Maceió em 2014, das quais foram coletados dados socioeconômicos, clínicos (dosagens de glicemia, hemoglobina capilar e medida de pressão arterial), dietéticos e antropométricos, incluindo neste último o ganho ponderal gestacional, classificado em insuficiente, adequado e excessivo, segundo o Instituto de Medicina dos Estados Unidos. A associação do ganho ponderal excessivo com as variáveis independentes foi testada por meio de regressão de Poisson expressa pela Razão de Prevalência $(R P)$ e respectivos intervalos de confiança a 95\% (IC $\left.{ }_{95 \%}\right)$. Foram estudadas 403 gestantes com idade média de 24,08 \pm 6,01 anos, sendo que em relação ao ganho ponderal 19,9\% delas o tiveram insuficiente; 14,1\% adequado e 66,0\% excessivo, estando este último associado à hiperglicemia materna $\left(R P=1,35 ; I C_{95 \%}=1,17-1,57 ; p<0,001\right)$. O ganho ponderal excessivo foi frequente entre as gestantes avaliadas, com associação dessa variável com a hiperglicemia materna.

Palavras-chave Ganho de peso, Hiperglicemia, Cuidado pré-natal 


\section{Introduction}

The anthropometric evaluation in pregnancy is a low-cost and very useful procedure for the establishment of early and effective interventions during prenatal care, with a view to reduce maternal and fetal risks, where gestational weight gain should be used as an indicator of maternal nutritional status ${ }^{1}$.

The World Health Organization (WHO) and the Institute of Medicine of the United States $(\mathrm{IOM}-\mathrm{USA})^{2}$ recommend ranges of gestational weight gain, differentiated according to the pre-gestational maternal nutritional status; this recommendation was also adopted by the Brazilian Ministry of Health ${ }^{3}$. Thus, women with pre-gestational low-weight diagnosis should have a weight gain of 12.5 to $18.0 \mathrm{~kg}$; those considered eutrophic a weight gain of 11.0 to $16.0 \mathrm{~kg}$; those overweight from 7.0 to $11.5 \mathrm{~kg}$, and obese women from 5.0 to $9.0 \mathrm{~kg}^{2}$.

A systematic review of the epidemiology of weight gain during pregnancy states that its excessive form raises the maternal risk of obesity in the postpartum period, contributing to the increased prevalence of this condition ${ }^{4}$. In addition, it increases the chance of gestational diabetes mellitus, hypertensive disorders and there are reports of fetal cases of macrosomia, cephalopelvic disproportion, and perinatal asphyxia ${ }^{5,6}$.

In general, studies on the determinants of excessive weight gain during gestation are scarce, with emphasis on those related to worse socioeconomic conditions. The impairment of health and nutritional states has also been described as factors associated with this outcome $\mathrm{e}^{7-9}$.

The gestation is a critical period, in which nutritional status directly influences maternal and fetal health, requiring an increased attention to health services. Although insufficient weight gain persists as a public health problem, excessive weight gain is an issue that needs immediate attention in primary care, given the adverse consequences of this aggravation?.

Thus, the aim of the present study is to evaluate the factors associated with excessive weight gain in pregnant women from Maceió, capital of the Alagoas, Northeast Brazil.

\section{Methods}

This is a cross-sectional study was carried out in Basic Health Units (BHU) in the municipality of Maceió in the year 2014, located in the homonymous microregion and mesoregion of Eastern Alagoas, a northeastern macroregion of the country. The municipality, the largest in the state of Alagoas, considered medium-sized by the United Nations Development Program, had an estimated population of 1.005.319 inhabitants in 2014, and a human development index of $0.735^{10}$.

This study is part of a larger research for the Unified Health System (UHS), funded by the PPSUS/02/2013/FAPEAL, entitled "Nutritional status, weight gain and feeding behavior of pregnant women in Maceió-Alagoas: impact on health of the binomial mother-child" that also had as objective to evaluate the weight gain gestational and its associated factors.In the present study were included pregnant women with a single fetus and attended by the municipal public network from Maceió. Were excluded pregnant women who did not perform some of the study steps (anthropometry and/or food survey). Not included pregnant women that presented difficulties of locomotion and twin pregnancy. The sample calculation was performed using the Epi Info Version 7.0, considering as an outcome of interest the prevalence of excessive weight gain during pregnancy according to Assunção et al. ${ }^{11}$ estimated at $45 \%$, a sample error of $5 \%$, a confidence level of $95 \%$, would require 381 volunteers. Due to the availability of resources, 403 pregnant women who completed the research protocol (two 24-hour reminders) were included, out of a total of 432 volunteers from the original project, totaling a loss of 29 pregnant women.

It is emphasized that Maceió is strategically organized in eight health districts, covering the districts of the capital, with a total of $60 \mathrm{BHU}$. Thus, from a list of all the BHU of the capital was drawn $50 \%$ of the total by sanitary district (made by random lottery). Based on these data, a weighting calculation was performed according to the number of pregnant women enrolled in each BHU, a list provided by the Municipal Health Department of the municipality (Rede Cegonha) so that those units with more registered pregnant women contributed, proportionally, of pregnant women in the sample.

Recruitment of pregnant women was done in a random manner before the start of the prenatal consultations at BHU, where they were initially invited to participate in the research and guided to signing the informed consent form. In sequence, the questionnaire developed and tested previously by the research group was applied. The information collected included socioeconomic data (age, monthly family income, ma- 
ternal schooling, and marital status), prenatal (parity and gestational age), nutritional status (anthropometry and food consumption), and serum levels of hemoglobin, glucose, and blood pressure measurements. The data collection was done by students prior trained, and supervised by a nutritionist (ACMO)."

For the anthropometric evaluation, the variables of weight and height were measured using a Marte LC200 ${ }^{\circledR}$ digital scale and portable stadiometer. The gestational body mass index (BMI) was calculated, and using cut-off points established by Ministry of Brazil Health ${ }^{3}$ the pregnant women had the nutritional status classified as low weight, adequate, overweight, and obesity. Data of weight and pre-gestational BMI were also investigated, being these data referred by the pregnant woman considering age range also by Ministry of Brazil Health $^{3}$. The weight gain during pregnancy adjusted for gestational age at the time of the interview was evaluated to the $\mathrm{IOM}^{2}$ meta-weight recommendations, being classified as insufficient weight gain, adequate weight gain, or excessive weight gain (the latter, the variable outcome of the analyzes).

Two 24-hour dietary recall was used to evaluate the energy and macronutrient consumption, the first realized at the time of application of the survey questionnaire and the second by phone, with an interval of up to a month after the initial collection. Both the food assessment was corresponding to typical days in the week. The data were analyzed using the nutritional prescription and assessment system-Avanutri $4.0^{\circledR}$, with subsequent adjustments of calories and nutrients by the Estimated Average Requirement (EAR) method as a cut-off point ${ }^{12}$. The evaluation of the adequacy of food consumption was based on the existing recommendations for pregnant women according to the Dietary Reference Intakes (DRIs) ${ }^{13}$. Food intake was considered adequate when the frequency established by the average of the two food recall data collected was between the EAR corresponding to the Reference Dietary Intake and the Tolerable Upper Intake Level (UL), which is the tolerable upper limit of the intake ${ }^{12}$. The individual energy requirement and fiber recommendation were based Food and Agriculture Organization/ World Health Organization/United Nations University/Institute of Medicine ${ }^{14,15}$.

The blood pressure was measured using the Omron $705 \mathrm{CP}^{\circledR}$ device, with the women sitting comfortably for at least 5 minutes in a chair (with their feet flat on the floor), in a calm environment, and with the right arm positioned at heart level.
For the purpose of data analysis, the mean values obtained in two blood pressure measurements were used, with 20 minutes intervals. The systolic blood pressure $\geq 140 \mathrm{mmHg}$ and/or diastolic blood pressure $\geq 90 \mathrm{mmHg}$ were used as cut-off points for high blood pressure ${ }^{16}$.

In order to verify the presence of anemia, hemoglobin was measured by capillary blood samples using disposable microcuvettes using the Hemocue $^{\circledR}$ (Hemocue Limited, Sheffield - UK) portable photometer. The results were obtained immediately by reading the apparatus used and expressed in deciliters. Dosing was performed only once, but in the presence of hemoglobin $<10 \mathrm{~g} /$ $\mathrm{dL}$, the test was repeated and the result obtained by the mean of the two samples. For the diagnosis of anemia, the criterion proposed by the $\mathrm{WHO}^{17}$ was used, which defines as hemoglobin concentration below $11 \mathrm{~g} / \mathrm{dL}$, and for severe anemia $<7 \mathrm{~g} / \mathrm{dL}$.

Blood glucose measurements were made through the collection of capillary blood samples using Softclik disposable lancers and the Accu Check Performa portable digital glycol meter, both from Roche ${ }^{\circledR}$ Laboratory. The results were obtained immediately by reading the apparatus and expressed in $\mathrm{mg} / \mathrm{dL}$. The capillary dosage was performed once with a cut-off point of $140 \mathrm{mg} /$ $\mathrm{dL}$ according to the Brazilian Diabetes Society in its latest Directive ${ }^{18}$.

The independent variables studied were: age range ( $\leq 19$ years / 20 -34 years / $\geq 35$ years); monthly household income $\leq 1$ minimum wage (yes / no); no stable union (yes / no); schooling $\leq$ 4 years of study (yes / no); primigravida (yes / no); gestational age $\geq 20$ weeks (yes / no); high blood pressure (yes / no); hyperglycemia (yes / no); anemia (yes / no); nutritional status classified by gestational BMI (low weight, eutrophy, overweight and obesity), and high food (caloric, protein, lipid, and glucose) and low fiber intake.

The data were processed using Stata version 13.0. In the study, multiple Poisson logistic regression with robust variance estimation was used to identify associated factors with excessive gestational weight gain (dependent variable). The variables that were significantly less than $20 \%$ ( $p$ $<0.20$ ) in the univariate test were tested in the adjusted model. The magnitude of the associations between the independent variables and the outcome variable was expressed in Prevalence Ratio (PR) and respective Confidence Intervals (95\% $\mathrm{CI})$, considering a significant $\mathrm{p}<0.05$.

The present study was approved by the Ethics and Research Committee of the Federal University of Alagoas. 


\section{Results}

A total of 403 pregnant women with a mean age of $24.08 \pm 6.01$ years, ranging from 14 to 44 years old, were studied, with $24.3 \%$ of them adolescents. More than $50.0 \%$ of them (56.8\%) had monthly family income $\leq 1$ minimum wage; $43.9 \%$ were primigesta and $63.9 \%$ were gestational age $\geq 20$ weeks (Table 1 ). We excluded 29 pregnant women who did not complete the research protocol. There were no refusals.

Regarding nutritional status, $17.1 \%$ were underweight and $42.9 \%$ were overweight $(29.0 \%$ overweight and $13.9 \%$ were obese). According to gestational weight gain, $19.9 \%$ had insufficient gain; $14.1 \%$ adequate gain and $66.0 \%$ excessive gain. Regarding food consumption, $11.2 \%$, $21.3 \%, 13.9 \%$ of pregnant women presented high caloric, protein, lipid and glucose consumption, and $82.9 \%$ presented low consumption of dietary fiber (Table 1).

The results of the univariate analysis of the association between the independent variables and the excessive gestational weight gain are shown in Table 1, with association of the outcome after adjustment of the model only with maternal hyperglycemia $[\mathrm{PR}=1.389(95 \% \mathrm{CI}=$ 1.197-1.611); $\mathrm{p}<0.001$ ] (Table 2).

However, the variables pregnancy, maternal obesity, and high protein intake were also included in the adjusted model, since they were included in the criteria proposed for this last analysis ( $p$ $<0.20$ in the crude analysis).

\section{Discussion}

Adequate nutritional status and maternal weight gain are important factors for an adequate gestational outcome, as well as maternal and infant health maintenance over the years ${ }^{19,20}$. In this research, almost two-thirds of pregnant women presented excessive weight gain $(66.0 \%)$, a much higher frequency than that found in studies performed with Brazilian pregnant women in Campina Grande $(43.0 \%)^{21}$ and Rio Grande do Sul $(44.8 \%)^{22}$, and with pregnant women in Canada $(48.7 \%)^{8}$.

It is known that excessive weight gain during pregnancy contributes heavily to the obesity epidemic in modern times. The prevalence of this condition has been increasing and being a cause for alarm among health professionals ${ }^{23}$, and the fact that in this study those obese women had a greater weight gain compared to non-obese wom- en $(16.2 \%$ versus $9.5 \% ; \mathrm{p}=0.034)$. A similar result was found in a study carried out in Southern Brazil where a higher risk of excessive weight gain was observed in pregnant women with pre-gestational overweight and obesity (RR 1.75, 95\% CI 1.48-2.07 and RR: 1.55, 95\% CI: 1.23-1.96, respectively $)^{22}$, and in another study conducted with women in Scotland, UK, where significant associations were found between high maternal BMI and excessive weight gain ${ }^{24}$, and in the study with pregnant women in Rio Grande do Sul, where was observed that overweight women at conception had the lowest proportion of healthy weight gain during pregnancy ${ }^{20}$.

It is known that pregnancy is a complex process where adaptations occur in the metabolic and physiological mechanisms aiming to promote fetal growth and maintenance of maternal health. For this, are required a variety of genetic and environmental interactions ${ }^{25}$. It is worth mentioning in this process the leptin hormone, responsible for regulating food intake and energy expenditure, which has its production proportional to the amount of body fat ${ }^{26}$. However, overweight individuals may develop resistance to this action. A study ${ }^{27}$ carried out with pregnant women found a relationship between a certain genetic polymorphism of leptin with the development of pre-pregnancy overweight and obesity, as well as with excessive weight gain during pregnancy. In addition, all overweight women had higher concentrations of leptin in all trimesters of pregnancy.

On the other hand, women who are overweight or obese before becoming pregnant, or those who gain excessive weight during pregnancy, are more likely to retain weight gained during this period, which increases the risk for the development of future diseases ${ }^{28}$. However, it is still unclear whether the association between pre-gestational BMI and postpartum weight change are independent of other factors able of altering maternal weight standards in the postpartum period ${ }^{29}$.

In this context, a randomized trial ${ }^{30}$ was developed with Egyptian pregnant women to test the effect of dietary counseling on excessive weight gain during pregnancy. The intervention group presented higher rates of maternal weight gain according to the recommendations when compared to the control $(42.7 \%$ vs $13.9 \%$, respectively), allowing the authors to conclude that such intervention reduces the excessive weight gain proportion during pregnancy, as well as improves eating practices. Consequently, leading to better perinatal outcomes. 
Table 1. Univariate analysis of the association between socioeconomic variables, prenatal, nutritional, and clinical status, and excessive gestational weight gain among pregnant women assisted by the public health system in 2014, Maceió-AL.

\begin{tabular}{|c|c|c|c|c|}
\hline Variables & $\begin{array}{c}\text { Total } \\
\mathrm{n}=403 \\
(100 \%)\end{array}$ & $\begin{array}{c}\text { Excessive } \\
\text { weight gain } \\
\mathbf{n}=266 \\
(66.0 \%)\end{array}$ & $\begin{array}{c}\text { Gross RP } \\
\left(\mathrm{IC}_{95 \%}\right)\end{array}$ & p-value ${ }^{\rtimes}$ \\
\hline \multicolumn{5}{|l|}{ Socioeconomic data } \\
\hline \multicolumn{5}{|l|}{ Age group (years) } \\
\hline$\leq 19$ & 24.3 & 24.1 & $0.986(0.835-1.263)$ & 0.868 \\
\hline $20-34$ & 67.7 & 67.3 & 1.00 & \\
\hline$\geq 35$ anos & 7.9 & 8.6 & $1.09(0.872-1.380)$ & 0.427 \\
\hline Schooling $\leq 4$ years of study & 4.7 & 4.1 & $0.871(0.589-1.289)$ & 0.491 \\
\hline Monthly family income $\leq 1$ minimum wage & 56.8 & 55.0 & $0.930(0.808-1.070)$ & 0.314 \\
\hline Without stable union & 20.1 & 21.4 & $1.084(0.921-1.275)$ & 0.330 \\
\hline \multicolumn{5}{|l|}{ Of prenatal } \\
\hline Primigesta & 43.9 & 39.8 & $0.845(0.730-0.979)$ & 0.026 \\
\hline Gestational age $\geq 20$ weeks & 63.9 & 64.5 & $1.026(0.885-1.190)$ & 0.731 \\
\hline \multicolumn{5}{|l|}{ Nutritional status } \\
\hline \multicolumn{5}{|l|}{ Anthropometry (current BMI) } \\
\hline Low weight & 17.1 & 15.8 & $0.959(0.740-1.122)$ & 0.351 \\
\hline Eutrophy & 40.0 & 39.8 & 1.00 & \\
\hline Overweight & 29.0 & 28.2 & $0.959(0.819-1.124)$ & 0.612 \\
\hline Obesity & 13.9 & 16.2 & $1.194(1.013-1.408)$ & 0.034 \\
\hline \multicolumn{5}{|l|}{ Food consumption } \\
\hline High Caloric & 11.2 & 12.0 & $1.087(0.879-1.345)$ & 0.439 \\
\hline High Protein & 21.3 & 18.3 & $0.827(0.670-1.021)$ & 0.078 \\
\hline High Lipid & 13.9 & 14.5 & $1.052(0.859-1.289)$ & 0.619 \\
\hline High Glycidic & 1.4 & 1.6 & $0.912(0.449-1.875)$ & 0.804 \\
\hline Low Fiber & 82.9 & 91.4 & $1.000(0.990-1.010)$ & 0.469 \\
\hline \multicolumn{5}{|l|}{ Clinical } \\
\hline Anemia & 27.7 & 27.9 & $1.012(0.866-1.182)$ & 0.878 \\
\hline High blood pressure & 3.0 & 3.0 & $1.011(0.673-1.519)$ & 0.955 \\
\hline Hyperglycemia & 5.4 & 7.7 & $1.438(1.244-1.663)$ & $<0.001$ \\
\hline
\end{tabular}

${ }^{*}$ Univariate Poisson regression, $\mathrm{p}<0.05$ as significant; RP - Prevalence ratio; $\mathrm{CI}_{95 \%}-95 \%$ Confidence Interval.

Current research on weight gain has shown a tendency to decline in adequate gestational weight gain in detriment to the increase in excessive weight gain ${ }^{6,9}$, the latter related to the cesarean delivery route, with the birth of preterm newborns, neural tube defects, macrosomia, higher admission rates in Pediatric Intensive Care Units, and increased risk of preeclampsia ${ }^{31,32}$, where in a recent study carried out in the public health system of Maceió municipality, obesity and excessive weight gain in pregnant women with preeclampsia when compared to those without the disease $(\mathrm{p}<0.001 \text { and } \mathrm{p}=0.013 \text {, respectively })^{33}$.

Added to that, a study carried out in a public maternity hospital in Rio de Janeiro also showed
Table 2. Multivariate analysis of factors associated with excessive gestational weight gain among pregnant women assisted by the public health system in 2014, Maceió-AL.

\begin{tabular}{lcr}
\hline \multicolumn{1}{c}{ Variables } & $\begin{array}{c}\text { RP adjusted } \\
\left(\mathbf{C I}_{\mathbf{9 5 \%} \%}\right)\end{array}$ & p-value* $^{\star}$ \\
\hline Hyperglycemia & $1.389(1.197-1.611)$ & $<0.001$ \\
Primigesta & $0.870(0.735-1.030)$ & 0.108 \\
Obesity & $1.145(0.948-1.384)$ & 0.158 \\
Excessive protein intake & $0.853(0.677-1.074)$ & 0.177 \\
\hline
\end{tabular}

${ }^{*}$ Multivariate Poisson regression, $\mathrm{p}<0.05$ as significant; RP Prevalence ratio; $\mathrm{CI}_{95 \%}-95 \%$ Confidence Interval. 
an increase in the risk of preeclampsia in overweight pregnant women ${ }^{23}$. Data from the international, multicenter and epidemiological Hyperglycemia and Adverse Pregnancy Outcome $(\mathrm{HAPO})^{34}$, which included 15 centers in 9 countries, concluded that a high maternal BMI was associated with a higher frequency of the disease.

An interesting fact in the present study was the association of excessive weight gain with maternal hyperglycemia, which may lead to the development of gestational diabetes mellitus in this group, a hypothesis already confirmed by the study by Zhong et al..$^{35}$ who concluded that the excessive early gestational weight gain is a significant risk factor for the onset of gestational diabetes mellitus.

The relationship between overweight and gestational diabetes assumes that in women already prone to insulin resistance due to obesity or genetic predisposition, the physiological tendency of pregnancy is increased, leading to exacerbation of hormones against insulin regulators, causing hyperglycemia and consequently the onset of gestational diabetes mellitus, usually diagnosed around the 20th to 24th weeks of pregnancy ${ }^{36}$.

In this context, data from Vigitel ${ }^{37}$ show a significant temporal variation, considering data from 2006-2016, between overweight indicators $\left(\right.$ BMI $\left.\geq 25 \mathrm{~kg} / \mathrm{m}^{2}\right)$, obesity $\left(\right.$ BMI $\left.\geq 30 \mathrm{~kg} / \mathrm{m}^{2}\right)$, medical diagnosis of arterial hypertension and medical diagnosis of diabetes. Despite the increasing trend of such indicators in both sexes, women presented variation coefficient superior to men in all of them except for hypertension. This reinforces the need for a greater care to the health of this public, considering that the excessive weight gain during the gestational period, as well as its maintenance, is risk factors for the evaluated conditions ${ }^{38}$.

In this research, it is important to note that a good part of the pregnant women studied had more than 4 years of study, without association of the outcome studied with this variable, nor with the other socioeconomic variables evaluated. This fact can be justified by the homogeneity of the studied sample, since all the pregnant women come from the public health network of the municipality. However, in the study carried out with pregnant women in two municipalities of the state of Rio de Janeiro, it was observed that the higher the schooling in years of study, the greater the chance of overweight during pregnancy'. In another study, in southern Iran, the proportion of excessive weight gain was lower among pregnant women with higher education $(>12 \text { years })^{39}$.

In the present study, there was no association between excessive weight gain in pregnancy and high energy, macronutrient and fiber consumption. However, studies relate inadequate dietary patterns during pregnancy with excessive weight gain in this period ${ }^{40,41}$ with an association between increased dietary energy density and the food pattern characterized by fast food foods (sweets, chocolates, processed meat, others) in the gestational period with increased weight gain at the end of pregnancy. This suggests that processed foods measure an aspect of diet that is independent of total energy and total fat intake ${ }^{41}$.

In addition, in a previous study, a positive association between energy intake and maternal weight gain was observed until the end of the gestational, as well as the carbohydrate intake or consumption of monosaccharide and saccharose was taken into account ${ }^{42}$. In the study Pathirathna et al. ${ }^{43}$ suggest that second trimester maternal carbohydrate intake has significant impacts on total gestational weight gain and neonatal birth weight. In a study carried out in Porto Alegre (RS), they highlight the effective interventions used to reduce the speed of weekly weight gain in overweight pregnant women. The prevalence of overweight pregnant women who gained more than $10 \mathrm{~kg}$ in 20 weeks was higher ( $\mathrm{RR}=0.4 ; 95 \%$ $\mathrm{CI}=0.19-0.96)$ in the control group (29.1\%), when compared to the Intervention group $(12.5 \%)^{44}$. In particular, consumption of ample vegetables, fruits, whole grains, and lean meats, and limited consumption of alcohol, caffeine and foods high in saturated fat during pregnancy has been recommended ${ }^{45,46}$. Evidence has emerged showing that consumption of foods high in sug$\mathrm{ar}^{47}$, saturated fat ${ }^{48}$ and sodium ${ }^{49}$ during pregnancy can be particularly harmful to both the pregnant woman and their neonates. The study by Drehmer et al. ${ }^{50}$, it was seen that an inadequate consumption of fiber increases the risk of weight gain, foods with a high fiber content have been proposed to be more satiating, reduce hunger and decrease energy intake. Thus, it is incumbent upon health professionals to focus on gestational weight gain, as well as to encourage the practice of healthy eating and promote educational actions that lead to their promotion, because the idea of "eating for two" during pregnancy still prevails, even though it has no scientific basis, thus favoring excessive weight gain ${ }^{51}$.

There is a need to conduct longitudinal and population-based studies to better clarify the 
problem, since the recognition and control of these factors may contribute to the prevention of possible complications during pregnancy.

In view of the above, it is evident the importance of nutritional care not only during pregnancy, but also in the pre-gestational period, considering that the maternal nutritional status prior to gestation and the gestational weight gain have a great influence on the health of the mother-fetus. Therefore, during the prenatal routine that occurs in basic care, special zeal must be used in the food consumption of these women with the objective of promoting the health of this public; as well as in the postpartum period, where the retention of the acquired weight may constitute a risk factor for the development of chronic diseases, besides the incorporation of such risks for a future pregnancy ${ }^{38,52}$.

Additionally, in their study, Swift et al. ${ }^{53}$ pointed out that adequate nutritional care in prenatal care provides a window of opportunity for the development of improvements in the food standard, specifically benefiting the mother-child binomial. Furthermore, Claesson et al. ${ }^{54}$ observed in their study that a prenatal follow-up in an appropriate gestational weight gain program seems to have a positive effect on the woman's weight in up to six years postpartum, preventing complications and future risks.

\section{Conclusion}

There was a high frequency of excessive gestational weight gain among pregnant women in Maceió, with an association between this variable with maternal hyperglycemia. It is important a monitoring nutritional status during gestation and before and after it, especially in overweight women, in order to minimize possible gestational complications, and the need to monitor weight retention in the postpartum period and an adequate recovery of nutritional status. The identification of the maternal nutritional diagnosis, including the food consumption, and the monitoring of the weight gain during pregnancy should be actions instituted effectively in the prenatal routine. The results of the present study serve as subsidies for effective decision making and implementation of public policies in the SUS.

\section{Collaborations}

RC Ferreira and MCS Tenório participated in the collection and tabulation of data, the writing of the article and the final approval of the version to be published. CS Mello participated in the writing of the article and collaborated with the analysis and interpretation of the data. MB Tenório participated in the writing of the article and in the final approval of the version to be published. ACM Oliveira worked on the final writing and relevant critical review of the intellectual content. 


\section{Acknowledgment}

To the Ministry of Health, to the National Scientific and Technological Development (CNPq), the Secretariat of Health of Alagoas (SESAU-AL) and to the Foundation for Research Support of the State of Alagoas (FAPEAL) for financial support; as well as to the interviewers responsible by the data collections and the Municipal Health Department Municipality of Maceió for technical and logistical support.

\section{References}

1. Santos MMAS, Baião MR, Barros DC, Pinto AA, Pedrosa PM, Saunders C. Estado nutricional prégestacional, ganho de peso materno, condições da assistência pré-natal e desfechos perinatais adversos entre puérperas adolescentes. Rev Bras Epidemiol 2012; 15(1):143-154.

2. Rasmussen KM, Yaktine AL, Institute of Medicine, National Research Council; Committee to Reexamine IOM Pregnancy Weight Guidelines. Weight gain during pregnancy: reexamining the guidelines. Washington: National Academies Press; 2009.

3. Brasil. Ministério da Saúde (MS). [Internet]. Orientações para a coleta e análise de dados antropométricos em serviços de saúde: Norma Técnica do Sistema de Vigilância Alimentar e Nutricional-SISVAN. Brasília: MS; 2011. [cited 2017 Mar 4]. Available from: http:// bvsms.saude.gov.br/bvs/publicacoes/orientacoes_coleta_analise_dados_antropometricos.pdf

4. Triunfo S, Lanzone A. Impact of overweight and obesity on obstetric outcomes. J Endocrinol Invest 2014; 37(4):323-329.

5. Zhao R, Xu L, Wu ML, Huang SH, Cao XJ. Maternal pre-pregnancy body mass index, gestacional weight gain influence birth weight. Women and Birth 2018; 31(1):e20-e25.

6. Çalik KY, Yildiz NK, Erkaya R. Effects of gestacional weight gain and body mass index on obstetric outcome. Saudi J Biol Sci 2018; 25(6):1085-1089.

7. Jebeile H, Mijatovic J, Louie JCY, Prvan T, Brand-Miller JC. A systematic review and metaanalysis of energy intake and weight gain in pregnancy. Am J Obst Gynecol 2016; 214(4):465-483.

8. Kowal C, Kuk J, Tamim H. Characteristics of weight gain in pregnancy among Canadian women. Matern Child Health J. 2012; 16(3):668-676.

9. Marano D, Gama SGN, Pereira APE, Paulo Souza RB. Adequação do ganho ponderal de gestantes em dois municípios do Estado do Rio de Janeiro (RJ), Brasil 2008. Rev Bras Ginecol Obstet 2012; 34(8):386-393.

10. Instituto Brasileiro de Geografia e Estatística (IBGE). Cidades@ [Internet]. Rio de Janeiro: IBGE; 2014 [cited 2016 Apr 09]. Avaliable from: http://www. cidades.ibge.gov.br/painel/painel.php?lang=\&codmun $=270430 \&$ search $=\% 7 C \% 7$ Cinfogr $\% E 1$ ficos:-dados-gerais-do-munic\%EDpio

11. Assunção PL, Melo ASO, Gondim SSR, Benício MHD, Amorim MMR, Cardoso MMA. Ganho ponderal e desfechos gestacionais em mulheres atendidas pelo Programa de Saúde da Família em Campina Grande, PB (Brasil). Rev Bras Epidemiol 2007; 10(3):352-360.

12. International Life Science Institute do Brasil (ILSI Brasil). Uso e aplicações das "Dietary Reference Intakes" DRIs. São Paulo: ILSI Brasil; 2001.

13. National Academy Press. Dietary reference intakes for vitamin A, vitamin $K$, arsenic, boron, chromium, copper, iodine, iron, manganese, molybdenum, nickel, silicon, vanadium, and zinc. Washington: National Academy Press; 2002. 
14. Food and Agriculture Organization (FAO), World Health Organization (WHO), United Nations University (UNU). Human energy requirements: report of a joint $\mathrm{FAO} / \mathrm{WHO} / \mathrm{UNU}$ expert consultation. FAO. Food and nutrition technical report series. ISSN 18133932. Rome, 17-24 oct, 2001. Geneva: FAO/WHO/ ONU; 2004.

15. Institute of Medicine. Dietary reference intakes for energy, carbohydrate, fiber, fat, fatty acids, cholesterol, protein, and amino acids. Washington: National Academy Press; 2005.

16. VI Diretriz Brasileira de Hipertensão Arterial. Arq Bras Cardiol. 2010; 95(1 Supl.1):1-5.

17. Benoist B, McLean E, Egli I, Cogswell M. World wilde prevalence of anaemia 1993-2005: WHO Global Database on Anaemia. Geneva: WHO; 2008

18. Oliveira JEP, Vencio S, organizadores. Diretrizes da Sociedade Brasileira de Diabetes: 2014-2015. São Paulo: AC Farmacêutica; 2014.

19. Diemert A, Lezius S, Pagenkemper M, Hansen G, Drozdowska A, Hecher K, Arck P, Zyriax BC. Maternal nutrition, inadequate gestational weight gain and birth weight: results from a prospective birth cohort. $B M C$ Pregnancy and Childbirth 2016; 16:224.

20. Marmitt LP, Gonçalves CV, Cesar JA. Healthy gestational weight gain prevalence and associated risk factors: A population-based study in the far South of Brazil. Rev Nutr 2016; 29(4):445-455.

21. Tavares JS, Melo ASO, Amorim MMR, Barros VO, Benício MHD, Takito MY, Cardoso MAA. Associação entre o padrão de atividade física materna, ganho ponderal gestacional e peso ao nascer em uma coorte de 118 gestantes no município de Campina Grande, Nordeste do Brasil. Rev Assoc Med Bras 2009; 55(3):335-341.

22. Drehmer M, Camey S, Schmidt MI, Olinto MTA, Giacomello A, Buss C. Socioeconomic, demographic and nutritional factors associated with maternal weight gain in general practices in Southern Brazil. Cad Saude Publica 2010; 26(5):1024-1034.

23. Seabra G, Padilha PC, Queiroz JA, Saunders C. Sobrepeso e obesidade pré-gestacionais: prevalência e desfechos associados à gestação. Rev Bras Ginecol Obstet 2011; 33(11):348-353.

24. Reynolds M, Osmond C, Phillips DIW, Godfrey KM Maternal BMI, Parity, and Pregnancy Weight Gain: Influences on Offspring Adiposity in Young Adulthood. J Clin Endocrinol Metab 2010; 95(12):5365-5369.

25. Talbot L, Maclennan K. Physiology of pregnancy. Anasthesia \& Intensive Care Medicine 2016; 17(7):341345 .

26. Li S, Li X. Leptin in normal physiology and leptin resistance. Science Bulletin 2016; 61(19):1480-1488.

27. Martins MC, Trujillo J, Farias DR, Kac G. Polymorphisms in the leptin (rs7799039) gene are associated with an increased risk of excessive gestational weight gain but not with leptin concentration during pregnancy. Nutr Res 2017; 47:53-62.

28. Chodankar R, Middleton G, Lim G, Mahmood T. Obesity in pregnancy. Obstetrics, Gynaecology \& Reproductive Medicine 2018; 28(2):53-56.
29. Schneider CR, Biggio JR, Chandler-Laney PC. Association of early pregnancy body mass index with post-partum weight change among African-American women. Clin Obes 2018; 8(3):170-175.

30. Abdel-Aziz SB, Hegazy IS, Mohamed DA, Abu EL Kasem MMA, Hagag SS. Effect of dietary counseling on preventing excessive weight gain during pregnancy. Public health 2018; 154:172-181.

31. Marchi J, Berg M, Dencker A, Olander EK, Begley C. Risks associated with obesity in pregnancy, for the mother and baby: a systematic review of reviews. Obes Rev 2015; 16(8):621-638.

32. Zhao R, Xu L, Wu ML, Huang SH, Cao XJ. Maternal pre-pregnancy body mass index, gestational weight gain influence birth weight. Women and Birth 2017; 31(1):e20-e25.

33. Oliveira ACM, Santos AA, Bezerra AR, Barros AAR, Tavares MCM. Fatores Maternos e Resultados Perinatais Adversos em Portadoras de Pré-eclâmpsia em Maceió, Alagoas. Arq Bras Cardiol 2016; 106(2):113120.

34. HAPO Study Cooperative Research Group. Hyperglycaemia and Adverse Pregnancy Outcome (HAPO) study: associations with maternal body mass index. BJOG 2010; 117(5):575-584.

35. Zhong C, Li X, Chen R, Zhou X, Liu C, Wu J, Xu S, Wang W, Xiao M, Xiong G, Wang J, Yang X, Hao L, Yang N. Greater early and mid-pregnancy gestational weight gain are associated with increased risk of gestational diabetes mellitus: A prospective cohort study. Clin Nutr ESPEN 2017; 22:48-53.

36. Moore STA, Waring ME, Callaghan K, Leung K, Ward Harvey M, Buabbud A, Chasan-Taber L. Weight gain in early pregnancy and risk of gestational diabetes mellitus among Latinas. Diabetes Metab 2017; 45(1):26-31.

37. Brasil. Ministério da Saúde (MS). Vigitel Brasil 2017: vigilância de fatores de risco e proteção para doenças crônicas por inquérito telefônico. Brasília: MS; 2017.

38. Tebanni F, Oulamara H, Agli A. Effects of gestational weigth gain on pregnancy complications. Nutrition Clinique et Métabolisme. 2018; 32(1):27-32.

39. Tabatabaei M. Gestational weight gain, pre-pregnancy body mass index related to pregnancy outcomes in Kazerun, Fars, Iran. J Prenat Med 2011; 5(2):35-40.

40. Martins APB, Benicio MHD. Influência do consumo alimentar na gestação sobre a retenção de peso pós -parto. Rev Saude Publica 2011; 45(5):870-877.

41. Rohatgi KW, Tinius RA, Cade WT, Steele EM, Cahill AG, Parra DC. Relationships between consumption of ultra-processed foods, gestational weight gain and neonatal outcomes in a sample of US pregnant women. Peer J 2017; 7(5):e4091.

42. Diemert A, Lezius S, Pagenkemper M, Hansen G, Drozdowska A, Hecher K, Arck P, Zyriax BC. Maternal nutrition, inadequate gestational weight gain and birth weight: results from a prospective birth cohort. $B M C$ Pregnancy and Childbirth 2016; 16:224.

43. Pathirathna ML, Sekijima K, Sadakata M, Fujiwara N, Muramatsu Y, Wimalasiri KMS. Impact of Second Trimester Maternal Dietary Intake on Gestational Weight Gain and Neonatal Birth Weight. Nutrients 2017; 9(6):627. 
44. Vitolo MR, Bueno MSF, Gama CM. Impacto de um programa de orientação dietética sobre a velocidade de ganho de peso de gestantes atendidas em unidades de saúde. Rev Bras Ginecol Obstet 2011; 33(1):13-19.

45. National Health and Medical Research Council (NHMRC). National Health and Medical Research Council (NHMRC). Healthy eating during your pregnancy. 2013. [cited 2017 Mar 4]. Available from: https://www.eatforhealth.gov.au/sites/default/files/files/ the_guidelines/n55h_healthy_eating_during_pregnancy.pdf

46. National Health Service (NHS). National Health Service (NHS). Foods to avoid in pregnancy. 2017. [cited 2017 Mar 4]. Available from: https://www.nhs.uk/ conditions/pregnancy-and-baby/pages/foods-to-avoid- Pregnant.aspxhttps://www.nhs.uk/conditions/ pregnancy-and-baby/pages/foods-to-avoid-pregnant. aspx

47. Petherick ES, Goran MI, Wright J. Relationship between artificially sweetened and sugar-sweetened cola beverage consumption during pregnancy and preterm delivery in a multi-ethnic cohort: analysis of the Born in Bradford cohort study. Eur J Clin Nutr 2014; 68(3):404-407.

48. Park S, Kim MY, Baik SH, Woo JT, Kwon YJ, Daily JW, Park YM, Yang JH, Kim SH. Gestational diabetes is associated with high energy and saturated fat intakes and with low plasma visfatin and adiponectin levels independent of prepregnancy BMI. Eur J Clin Nutr 2013; 67(2):196-201.

49. Tay S, Blache D, Gregg K, Revell D. Consumption of a high-salt diet by ewes during pregnancy alters nephrogenesis in 5-month-old offspring. Animal 2012; 6:1803-1810.
50. Drehmer M, Camey SA, Nunes MA, Duncan BB, Lacerda M, Pinheiro AP, Schmidt MI. Fibre intake and evolution of BMI: from pre-pregnancy to postpartum. Public Health Nutr 2013; 16(8):1403-1413.

51. Pathirathna ML, Sekijima K, Sadakata M, Fujiwara N, Muramatsu Y, Wimalasiri K. Impact of Second Trimester Maternal Dietary Intake on Gestational Weight Gain and Neonatal Birth Weight. Nutrients 2017; 6:627.

52. Wilcox S, Liu J, Addy CL, Turner-McGrievy G, Burgis JT, Wingard E, Dahl AA, Whitaker KM, Schneider L, Boutté AK. A randomized controlled trial to prevent excessive gestational weight gain and promote postpartum weight loss in overweight and obese women: Health In Pregnancy and Postpartum (HIPP). Contemp Clin Trials 2018; 66:51-63.

53. Swift JA, Langley-Evans SC, Pearce J, Jethwa PH, Taylor MA, Avery A, Ellis S, McMullen S, Elliott-Sale KJ. Antenatal weight management: Diet, physical activity, and gestational weight gain in early pregnancy. Midwifery 2017; 49:40-46.

54. Claesson M, Josefsson A, Sydsjö G. Weight six years after childbirth: A follow-up of obese women in a weight-gain restriction programme. Midwifery 2014; 30(5):506-511.

Article submitted 10/07/2017

Approved 26/11/2018

Final version submitted 28/11/2018 